\title{
DIVINE TESTING AND THE COVID PANDEMIC: Searching for Hope in Sufi Commentaries ${ }^{1}$
}

\author{
Peter G Riddell \\ SOAS University of London, United Kingdom \\ University of Sydney, Australia \\ petergriddell@gmail.com
}

Article History: Received: 4 October 2021; Accepted: 22 November 2021; Published:17 December 2021

\begin{abstract}
:
The Qur'an carries many references to the created world being subjected to divine testing. It, therefore, seems obvious to ask whether the COVID pandemic that has caused so much suffering across the world and continues to ravage communities represents a test by God for faithful believers. Tests can be daunting experiences, causing apprehension and fear. To what extent should faithful believers regard the COVID pandemic as a fearful, traumatic experience? On the other hand, how can believers find ways to focus on a sense of hope in the midst of the current troubles? This paper will initially consider a range of responses to the COVID pandemic by religious leaders and commentators. It will then draw out Qur'an verses referred to in these responses and will engage with these verses through the lens of several Sufi commentaries, in a search for layered meanings below a surface reading of the verses concerned.
\end{abstract}

Keywords: Allegory; COVID-19; Divine Testing; Hope; Sufi Tafsir

\section{A. Introduction}

7 he $21^{\text {st }}$ century has brought great trials to Southeast Asian communities of all faiths. The 2004 Boxing Day tsunami caused around 250,000 deaths. The current COVID pandemic is wreaking havoc, with an eventual death toll in the region that will likely surpass that of the tsunami.

COVID does not differentiate by faith, with large numbers of victims among Muslims, Christians, Buddhists, Hindus, and others. Some bleak interpretations of the causes of the pandemic have been offered by religious spokespeople, none more so than that offered by Islamic State spokesman Abu Hamzah al-Quraishi, who declared "God, by his will, sent a punishment to tyrants of this time and their followers ... which can't be seen by the naked eye. Today we are pleased for this punishment of God for you." As

1 I am most grateful to Professor Ismail Albayrak of the Australian Catholic University for his helpful comments on a draft of this paper. 
for the recommended response to the pandemic, the Islamic State spokesman proposed Jihad, urging fighters "everywhere to prepare whatever strength they could and be as hard as they could on the enemies of God and to raid their places. Don't let a single day pass without making their lives awful."'2

It might be expected that a group like Islamic State would offer such an angry, threatening, and extreme explanation for the COVID pandemic. But how extreme is it? In the following discussion, we will first consider how mainstream Muslim scholars in Southeast Asia are explaining the COVID pandemic to their respective religious communities. We will then turn our attention to a selection of Sufi commentaries and consider how they assist in understanding the concept of divine testing. We will conclude by drawing lessons from the Sufi commentaries consulted that can help Muslims negotiate their way through the COVID pandemic.

\section{B. Causes}

Muslim scholars and commentators across Southeast Asia contest the causes of the pandemic. University academics have been quick to offer analyses of its causes. Ustadz Haerul Akmal, Lecturer at the private Islamic University of Darussalam Gontor, Ponorogo, East Java, commented that "Allah, the wisest, wants to test His servants, which of them remains upright in carrying out all God's commands and upright in avoiding all heinous deeds, which can damage religion, soul, mind, lineage, and property." 3

Suyadi, Nuryana, and Fauzi, scholars at the Universitas Ahmad Dahlan, Yogyakarta, Indonesia, essentially agree but cast a slightly different spin on the perspective by urging a sense of optimism:

"Disaster management in Islam is very much determined by the perspective to interpret disaster. In the Qur'an, Sūra al-Baqara (2): 155, it is stated that a disaster is a form of love from Allah SWT and a medium of introspection. Therefore, disasters must be treated as a test, which opens up opportunities for people to improve the quality of their faith and devotion. Thus, disasters in Islam must be overcome with the spirit of a better life, not fatalistic and pessimistic." 4

2 Hesham Abdul Khalek, Ahmed Tolba, and Ulf Laessing, "Islamic State Calls COVID-19 God's Punishment for Foes: Tape," Reuters, May 29, 2020, https://www.reuters.com/article/us-healthcoronavirus-islamicstate-idUSKBN2343B9. accessed 16 Aug 2021.

3 Yadi Jayasantika, "Ekonomi Sulit Akibat Pandemi Covid-19, Jangan Gundah Tetap Sabar Dan Istiqomah, Ini Tanda Allah Hapuskan Dosa," https://kabarbanten.pikiran-rakyat.com/, July 12, 2021, https://kabarbanten.pikiran-rakyat.com/syiar/pr-592208358/ekonomi-sulit-akibat-pandemi-covid-19jangan-gundah-tetap-sabar-dan-istiqomah-ini-tanda-allah-hapuskan-dosa. com, accessed 10 August 2021.

4 Suyadi, Zalik Nuryana, and Niki Alma Febriana Fauzi, "The Fiqh of Disaster: The Mitigation of Covid-19 in the Perspective of Islamic Education-Neuroscience," International Journal of Disaster Risk Reduction 51 (December 2020): 101848, https://doi.org/10.1016/j.ijdrr.2020.101848. 
Across the Straits of Malacca, leading Malaysian Islamist politician Abdul Hadi Awang is assertive in declaring COVID-19 to be "a test from God and only Allah can overcome the battle against the disease ... whatever is happening is the will of Allah and no power can challenge His will." "It's hard to discern a sense of optimistic hope in such a statement. In a similar vein, former Malaysian Prime Minister Tan Sri Muhyiddin Bin Haji Mohd Yassin alludes to the overriding hand of God as the cause of the pandemic in stating in a speech that "I believe that God will not test or burden us with something that we cannot withstand", ${ }^{6}$ attempting to give both an explanation and a sense of hope in the process.

Prof. Mohd Aderi Che Noh of Sultan Idris University of Education, writing in the daily Berita Harian, went so far as to suggest that though unpleasant, COVID has good effects, quoting verse 216 of Qur'an chapter 2 which states "It may be that you hate something, when it is very good for you, and it may be that we like something when it is very bad for you. Allah knows while you do not know." 7 The Indonesian scholars Suyadi, Nuryana, and Fauzi, agree, commenting as follows: ${ }^{8}$

"In the perspective of Fiqh Kebencanaan (Coping with Disaster), Covid-19 is not merely a health disaster. It can be seen as a form of God's love and affection for humans. People who hold his belief will see that everything that God has given is "good". This perspective is based on theological arguments in several religious texts, such as QS. al-An'am (6): 54, QS. an-Naḥl (16): 30, QS. 'Alī 'Imrān (3): 18; QS. al-A'rāf (7): 29; QS. ash-Shūrā (42): 17, and QS. an-Naḥl (16): 29.”

In Singapore, Muslim spokespeople have been more circumspect addressing the causes of the pandemic. A Singaporean Muslim religious teacher who posted a statement on Facebook suggesting that the novel coronavirus was retribution by Allah against the Chinese for oppressing Muslim Uighurs was investigated by both the government Ministry of Home Affairs and the Islamic Religious Council of Singapore (MUIS). ${ }^{9}$ Mr. Ali Mohd, a spokesman for MUIS, said "We should not assume that a tragedy is indeed

5 FMT Reporters, "Covid Is Test from God, Only Allah Can Overcome It, Says Hadi Free Malaysia Today (FMT)," https://www.freemalaysiatoday.com/, July 5, 2021, https:/www.freemalaysiatoday.com/category/nation/2021/07/05/covid-is-test-from-god-only-anislamic-govt-can-overcome-it-says-hadi/. accessed 16 Aug 2021.

6 Muhyiddin Yassin, "Speech By YAB Tan Sri Muhyiddin Bin Haji Mohd Yassin Prime Minister of Malaysia” (Malaysia, April 1, 2020), https:/www.pmo.gov.my/wp-content/uploads/2020/04/EnglishPM-Speech-PRIHATIN-Plus-6-4-2020-905pm.pdf. accessed 16 Aug 2021.

7 Mohd Aderi Che Noh, "Ujian COVID-19 Jadikan Manusia Dekat Dengan Tuhan,” Berita Harian, February 5, 2021, https://www.bharian.com.my/rencana/agama/2021/02/783387/ujian-covid-19jadikan-manusia-dekat-dengan-tuhan. accessed 16 Aug 2021.

8 Suyadi, Nuryana, and Fauzi, "The Fiqh of Disaster: The Mitigation of Covid-19 in the Perspective of Islamic Education-Neuroscience."

9 Alif Chandra, "Religious Teacher Under Investigation by MHA, Muis for Post Saying Novel Coronavirus Was Retribution from Allah against Chinese," Https://WWw.Todayonline.Com/, February 7, 2020, https://www.todayonline.com/singapore/religious-teacher-under-investigationmha-muis-racist-post-saying-novel-coronavirus-was. accessed 4 Aug 2021. 
God's retribution for a specific race or nation. We do not know the real reason or the wisdom behind God's actions," adding "Religious leaders and teachers must counter the irresponsible practice of using the spread of the novel coronavirus in many parts of the world to spread divisive and xenophobic views such as attributing the spread of the virus to the cultural practice of a certain community." 10

Many Muslim groups across the Southeast Asian region express similar caution, with the English language daily Jakarta Post carrying an article by Abdul Mu'ti, Secretary-General of Muhammadiyah mass civil society modernist organisation and lecturer at Syarif Hidayatullah State Islamic University Jakarta, in which he contrasts fundamentalist groups who argue that COVID is God's punishment with progressive groups who say it is a man-made disaster. ${ }^{11}$

Thus the above brief discussion has already unveiled some variety in explanations of the causes of the pandemic. The weight of opinion seems to lie on associating COVID with a divine test, though not all agree. Some portray such a test in threatening, fearful terms while others argue for a sense of optimism and hope in viewing the test. We will return to these different perspectives when we consider the tafsir $r$ literature later in this paper.

\section{Responses}

While statements relating to the causes of COVID can be found, as discussed above, more attention has been devoted in the literature to appropriate responses among Muslim groups and individuals.

One common response from Muslim leaders is to call for increased prayer and worship. Grand Imam of Jakarta's Istiqlal Mosque, Nasaruddin Umar, commented that "Apart from heeding health protocols, for us religious people, Muslims, we should maximize our worship. Let's also always pray, let's put our trust in Allah. Truly Allah loves those who put their trust in Him." ${ }^{12}$

This theme was enunciated in various media forums. Leading Indonesian Islamic newspaper Republika commented in one article that prayer can have mental health benefits: "as a believer, you can keep your stress level by continuing to pray, repeat the names of Allah, and meditate every day." As with many commentaries, the article in Republika quoted the Qur'an, in this case, chapter 2 verse 186, where Allah is speaking:

10 Alif Chandra, "Religious Teacher Under Investigation by MHA, Muis for Post Saying Novel Coronavirus Was Retribution from Allah against Chinese,"...

11 Abdul Mu'ti, "Religious Communities Join Fight against COVID-19," The Jakarta Post, June 12, 2020, https://www.thejakartapost.com/academia/2020/06/12/religious-communities-join-fightagainst-covid-19.html. accessed 5 Aug 2021.

12 Sartika Rizki Fadilah, "Optimis PPKM Berhasil, Imam Besar Istiqlal: Kalau Kita Kompak, Covid-19 Akan Allah Angkat Dari Indonesia," Galamedia News, July 23, 2021, https://galamedia.pikiranrakyat.com/news/pr-352266511/optimis-ppkm-berhasil-imam-besar-istiqlal-kalau-kita-kompakcovid-19-akan-allah-angkat-dari-indonesia?page=2. accessed Aug 15, 2021. 
"I grant the supplication of the one who prays when he prays to Me. Let them fulfill My (command) with obedience and trust Me and believe in Me, that they may find the truth." ${ }^{13}$ Indonesian President Joko Widodo acknowledged a religious dimension to responses to the crisis in stating in early 2020: "Under these conditions, it is time for us to work from home, learn from home, worship from home. This is the time to work together, to help each other, and be cooperative. We want this to be a community movement so that the problem is quickly resolved."14

Several groupings of Islamic religious scholars issued fatwas (legal opinions) supporting Government measures and affirming the acceptability of anti-COVID vaccines according to Islamic Law. Thus, immediately following President Widodo's above-mentioned appeal, the Indonesian Council of Religious Scholars (MUI) issued fatwa 14 on Organising Worship under the Conditions of the COVID-19 Outbreak, specifying (i) the substitution of congregational Friday prayers with the Zuhr prayer for those exposed to the coronavirus and in areas with high contagion potential; (ii) those in other areas to continue with congregational Friday prayers while following health protocols. ${ }^{15}$ On 11 January 2021 MUI issued a fatwa declaring the Sinovac vaccine to be "pure and recommended. ${ }^{16}$ The Islamic Religious Council of Singapore issued a fatwa on 6 May 2020 affirming that it was acceptable according to Islamic Law for the charitable payments collected by mosques (zakat) to be used for relief for people adversely affected by COVID. ${ }^{17}$

In the Southern Philippines, diverse Muslim organisations issued directives to their respective communities to adhere to government protocols regarding COVID, basing their responses on various sources: textual guidelines from Qur'an and Prophetic traditions regarding injunctions on plague (communicable diseases), opinion from Islamic legal scholars on protecting communities from harm, and scientific and medical information available on COVID-19. ${ }^{18}$

13 Mabruroh and Ani Nursalikah, "Menghadapi Covid-19 Dengan Tetap Percaya Kepada Allah" Republika Online," Republika.Co.Id, May 1, 2021, https://www.republika.co.id/berita/qsejj4366/menghadapi-covid19-dengan-tetap-percaya-kepadaallah. accessed 3 Aug 2021.

14 Amos Sukamto and S. Panca Parulian, "Religious Community Responses to the Public Policy of the Indonesian Government Related to the Covid-19 Pandemic," Journal of Law, Religion and State 8, no. 2-3 (December 16, 2020): 273-83, https://doi.org/10.1163/22124810-2020006..

15 Sukamto and Panca Parulian.

16 Komisi Fatwa Majelis Ulama Indonesia, "Fatwa MUI No 02 Tahun 2021 Tentang Produk Vaksin Covid-19 Dari Sinovac Life Sciences, Co. Ltd China Dan PT Biofarma - Majelis Ulama Indonesia," mui.or.id, January 20, 2021, https://mui.or.id/produk/fatwa/29485/fatwa-mui-no-02-tahun-2021tentang-produk-vaksin-covid-19-dari-sinovac-life-sciences-co-ltd-china-dan-pt-biofarma/. accessed 4 Aug 2021.

17 Office of the Mufti, "Fatwa on Zakat Assistance for Those Affected by Covid-19" (Singapore, May 6, 2020), https://www.muis.gov.sg/officeofthemufti/Fatwa/English-Zakat-Covid. accessed 15 Aug 2021.

18 Yusuf Roque Morales and Sheryl Renomeron Morales, "Responses to Fatwas of Islamic Religious Leaders and Institutions during the Coronavirus Disease (COVID-19) in the Philippines: Looking at How Guidance Was Provided to Muslim Communities in the Philippines," Turkish Journal of 
Additionally, many Muslim groups organized diverse relief activities. Muhammadiyah, the largest progressive Islamic movement in Indonesia, established the Muhammadiyah COVID-19 Command Center (MCCC), allocating millions of dollars for the fight against COVID-19 and involving over 60,000 medical, psychological, and social volunteers in its various programs held at almost 100 Muhammadiyah hospitals and health centers. ${ }^{19}$

\section{Reflections on Divine Testing}

Given the association of divine testing in the minds of many, perhaps most, Muslims with the COVID pandemic and other such disasters, it would be instructive to consider a set of key Qur'anic verses that refer to Allah's testing. In doing so, we will draw on the wisdom of a selection of tafsi $r$ works influenced by Sufi thinking, both classical and modern, from both Southeast Asia and beyond, to see if they can shed light on some of the varying perspectives on divine testing that we encountered in Section B of this paper. We recall that the issues at the debate were (a) whether COVID represented a divine test or not (b) whether such a test was a cause for fear or hope.

The Sufi works consulted were selected on the basis of clear association of the authors with Sufi orders or with prominent Sufis in such a way that the influence of Sufi thinking is seen in their works of tafsi $r$. The exegetes drawn on in following discussion are Sahl al-Tustarī, 'Abd al-Karīm ibn Hawāzin al-Qushayrī, 'Abd al-Razzāq Kamāl alDīn al-Kāshānī, Bediüzzaman Said Nursi, Hamka, and Haji Muhammad Sa'īd bin 'Umar. I have not drawn on works of tafsir $r$ where the authors themselves were clearly associated with Sufi orders but their commentary is not Sufi, such as 'Abd al-Ra'üf alFanșūrī's Tarjumān al-Mustafid.

A verse from the middle Meccan period that refers to divine testing is Al-Mulk 67:2:

... who created death and life to test you [people] and reveal which of you does best ${ }^{20}$ - He is the Mighty, the Forgiving;

This verse is important in providing the believers with an understanding of what they must do to receive a positive outcome at the final judgment. Does this verse merely point to a requirement of doing good deeds, following the dictates of the law, and undertaking the five pillars? The famous $9^{\text {th }}$ century Persian Sufi exegete Sahl al-Tustari (818-896) thinks otherwise, providing us with an early Sufi insight into meanings that underlie the surface text of the Qur' an. Explaining his understanding of ahsanu 'amalan, al-Tustarī writes:

\footnotetext{
Computer and Mathematics Education 12, no. 10 (2020): 6160-65, https://doi.org/10.2139/ssrn.3678425.

19 Abdul Mu'ti, "Religious Communities Join Fight against COVID-19."

20 Li-yabluwakum ayyukum ahsanu 'amalan.
} 
"If he is correct [in conduct] but not sincere, he will not be accepted; while if he is sincere, but not correct [in conduct] he will not be accepted either. [He will not be accepted] until he is at the same time correct and sincere [in his conduct]. The one who is sincere (khäliss) is he who [lives] for God, Exalted is He, with the full intention (irā da) of his heart, while the one who is correct (șawāb) is he who is on the path of the Sunna and [lives] in accordance with the Book." 21

Sahl's exegesis is nuanced and perceptive. He has taken the two-word phrase of the Qur' an ahsanu 'amalan and done what a good exegete should do: consider its surface meaning as well as underlying deeper meanings. The result is that he is stressing the importance of both faiths, with the conviction of the heart, and deeds for the believer, not simply outward deeds as might be understood by a surface reading of ahsanu 'amalan.

Another Qur'anic exegete who has strong Sufi credentials who comes from the modern age is Bediüzzaman Said Nursi (1878-1960), whose life was divided almost equally between Ottoman and Republican Turkey and who is arguably one of the greatest Islamic theologians of the modern period. In his work Signs of Miraculousness, which forms part of his monumental commentary Risale-i Nur, Nursi begins his commentary on QS. 67:2 as follows: "Consider this: the verse 'He who created death and life' (67:2) shows that death is not annihilation and absolute non-existence; it is rather an act, a change of abode, and the spirit's liberation from its place of confinement." 22 Here we have a clear sense of hope presented to his readers, many, perhaps most, of whom would have a nat ural feeling of apprehension about the prospect of dying. Yesilhark explains how Nursi gives four reasons how death can be a bounty:

"The first reason is that death frees man from the duties and obligations of life ...

Secondly, Nursi states, it ... unites one with the mercy of the Eternal Beloved One.

Thirdly, he states the numerous factors which make life a burden ... Fourthly, Nursi

compares death with sleep saying that death is like the older brother of sleep..."23

The lessons that we can take from these examples from Sahl al-Tustarī and Said Nursi are twofold: first, the importance of looking for both surface and underlying meanings in the Qur'anic message, not just being satisfied with literal readings of the verses; second, death should be associated with hope and optimism, not fear and pessimism.

A late Meccan verse that refers to a process of divine testing is Al-Ankabūt 29:2:

21 Sahl b. 'Abd Allāh Al-Tustarī, Tafs̄in Al-Tustañ: Great Commentaries on the Holy Qur'ān, ed. Annabel Keeler and Ali Keeler (Amman: Royal Aal al-Bayt Institute for Islamic Thought, 2011), 24041.

22 Bediüzzaman Said Nursi, Signs of Miraculousness: The Inimitability of The Qur'an's Conciseness, ed. Şükran Vahide (Istanbul: Şözler Publications A.Ş, 2013), 244-45.

23 Tubanur Yesilhark, “A Proper Way to Fear God and the Reality of Death," in God, Man and Mortality from the Perspective of Said Nursi (Durham: University of Durham, 2008), https://risaleinur.com/studies/137-conferences/2008/4047-a-proper-way-to-fear-god-and-the-realityof-death.html. accessed 6 Sep 2021. 
Do people think they will be left alone after saying 'We believe' without being put to the test [lä yuftanūna]?

Sahl al-Tustarî's tafsir makes a helpful return appearance at this point to show his use of allegory, a feature that is characteristic of much Sufi tafsì . Sahl is quite comfortable to include Sufi terminology in his commentary in explaining the meaning of "without being put to the test": "That is, without their being beset by affliction (balā'). Truly affliction is a doorway between the people of gnosis (ahl al-ma'rifa) and God, Mighty and Majestic is He." ${ }^{24}$ The "people of gnosis" are those with a special understanding of reality because of Sufi training and gifting. Sahl's use of allegory is extended by his taking the pillars of duty and explaining a deeper meaning for each:

"Let your prayer (salāt) be forbearance (sabr) in the face of suffering ( $b a$ 'sā'), your fasting (sawm) be to observe silence (samt), and your charity (sadaqa) be to refrain from doing harm [to anybody] ( kaff al-adha $)$. Furthermore, forbearance in [times of] well-being ('âfiya) is more difficult than forbearance in [times of] affliction (balā ). ${ }^{.25}$

A famous modern Qur'an commentator from Southeast Asia is Haji Abdul Malik Karim Amrullah, better known as Hamka (1908-1981). He came from a family that included both Sufi and anti-Sufi forebears, so his engagement with Sufism was creative, but he was not exclusively Sufi himself. His commentary on the Qur'an, while not a Sufi commentary, has elements that point to the Sufi influences that played out in his own life. ${ }^{26}$ His comment on QS. 29:2 carries echoes of the distinction between outward performance of duties also requiring commitment in the heart that we heard in Sahl alTustarī’s commentary on QS. 67:2 above:

"Allah will not allow a person to profess faith without being tested. Every faith must be tested. Faith that cannot stand testing is faith by the confession of the mouth [alone], not faith in the defense of the heart. ${ }^{27}$

The lessons that we can draw from the above comments on QS. 29:2 by Sahl and Hamka are an affirmation of the view that outward actions need to be accompanied by inward commitment in faith; furthermore, behind the ritualistic duties such as the pillars are allegorical meanings that believers should seek to understand.

A further late Meccan verse that mentions testing from God is Hud 11:7:

It is He who created the heavens and the earth in six Days - His rule extends over the waters too - so as to test which of you does best. Yet [Prophet], if you say to

24 Al-Tustarī, Tafsìr Al-Tustañ: Great Commentaries on the Holy Qur'ān, 149.

25 Al-Tustarī, Tafsìr Al-Tustañ: Great Commentaries on the Holy Qur'ān.

26 Syed Muhd. Khairudin Aljunied, Hamka and Islam: Cosmopolitan Reform in the Malay World (Singapore: ISEAS Publishing, 2018), 100-111.

27 "tidaklah akan dibiarkan saja oleh Allah seorang manusia mengaku beriman, padahal dia tidak diuji. Tiap-tiap iman pasti kena ujian. Iman yang tidak tahan karena ujian, barulah iman pengakuan mulut, belum iman pertahanan hati." Hamka, Tafsir Al-Azhar, 4th ed., vol. 7 (Singapore: Pustaka Nasional, 2001), 5394. 
them, 'You will be resurrected after death,' the disbelievers are sure to answer, 'This is clearly nothing but sorcery.'

Abd al-Razzāq Kamāl al-Dīn al-Kāshānī (d. ca 730/1330) was a medieval Sufi scholar who belonged to the school of the famous Andalusian Sufi Ibn 'Arabì (11651240), the founder of the stream of Sufism known as wahdat al-wujū d. Indeed, the authorship of al-Kāshānī's commentary, Tafs̄ì al-Qur'ān al-Kan̄m, is often attributed to Ibn 'Arabī himself. This work's commentary on QS. 11:7 provides a glimpse into some of the most lyrical and allegorical of Sufi exegesis:

"And $\mathrm{He}$ is Who created the heavens and the earth in six days, in other words, $\mathrm{He}$ created the corporeal world in six directions - and His Throne was upon the water, namely, His Throne which is the First Intellect founded upon the first knowledge and reinforced by it, preceding the corporeal world in terms of existence." 28

Again the Sufi commentator reminds the reader to look below the surface meaning, to avoid simple literalism. So "six days" refers to "six directions" of the "corporeal world" (khalaqa al-'ālam al-jasmāni fi sitta jihāt), while the "Throne" is the "First Intellect" ('arshuhu al-ladhì huwa al-'aql al-awwal). ${ }^{29}$ The complexities of wujūdi theosophy do not need to delay us here as our focus is on how Sufis can speak into the challenges faced by the ordinary Muslim faithful. What is important for our purposes is the restatement of the need to look for deeper meanings and significances in developments in daily life.

Another modern Southeast Asian Qur'an commentator, though not as well known as Hamka, is Haji Muhammad Said bin Umar (ca. 1854-1932), from the state of Kedah on the Malay Peninsula. He studied in Malaya, Pattani, and Arabia, and was a member of the Naqshbandiyya Sufi order. His commentary on the Qur'an entitled Tafsìr Nür alIhsān and in Jawi Malay, was published in four volumes and carries many influences from his Sufi formation. The following excerpt comes from his commentary on QS. 11:7:

"(He is Almighty God, the God who created the seven levels of the heavens and the earth in the fixed period of six days) because the sun was on the earth at that time, beginning Sunday and finishing Friday. (And His throne was over the water) and over the wind in their respective places as it is now, not spread over the water like a mat on a plank floor. Only the throne was above the seventh heaven, with the water below the seventh earth (in order to test which of you is most obedient) to Allah. (And if you say, "Truly you will be raised from the grave after your death" then all the disbelievers will say "This is not the Qur'an but magic) which is false because they do not believe in the Qur'an and resurrection from the grave." 30

28 'Abd al-Razzāq Al-Kāshānī, Great Commentaries on the Holy Qur'ān, Tafs̄̄r Al-Kāshānī, Part I Surahs 1-18 (Amman: Royal Aal al-Bayt Institute for Islamic Thought, n.d.), 320-21.

29 Ibn Al-'Arabī, Tafs̄ir Al-Shaykh Al-Akbar Al-'ārif Bi-Allāh Ta'ālā Al-'allāmah Muhyī Al-Dīn Ibn 'Arabī, vol. 1 (Beirut: Dār al-Ṣādir, n.d.), 293.

30 “(Ialah Allah Ta'alla itu Tuhan yang menjadi tujuh lapis langit dan bumi pada masa qadar enam hari) kerana bumi ada matahari ketika itu awalnya ahad akhirnya jum' at. (Dan adalah arsh-Nya atas air) dan ia atas angin pada tempat masing-masing, seperti sekarang ini, bukan terhantar atas air seperti tikar

Teosofia: Indonesian Journal of Islamic Mysticism, Vol. 10, No. 2, 2021

http://journal.walisongo.ac.id/index.php/teosofia 
Muhammad Said does not engage with sophisticated theosophical reflection like al-Kāshānī. However, they share a Sufi inclination to allegorize, making use of rhetorical devices to catch the attention of their audience. While al-Kāshānī allegorizes in ways beyond the comprehension of most ordinary Muslims, Muhammad Said seeks to do the opposite; namely, present the Qur'anic text in a way that his readers from Malay farming communities could relate to. So when the Qur'an refers to God's throne being spread over the water and the wind, Muhammad Said introduces the imagery of "like a mat on a plank floor" (seperti tikar atas lantai papan), a metaphor that would be well understood by his Malay readers.

The lesson to be taken from these comments on QS. 11:7 by al-Kāshānī and Muhammad Said is the importance of bringing the faithful on the journey with the exegete, opening their eyes to realities that might not occur to them, through allegory.

An early Medinan verse, QS. al-Baqara 2:216, poses certain interesting questions. The verse was quoted by Prof. Dr. Mohd Aderi Che Noh, as discussed in Section B above. However, he omitted a key part of the verse. The full verse in English translation reads as follows:

"Fighting is ordained for you, though you dislike it. You may dislike something although it is good for you, or like something, although it is bad for you: God knows and you do not."

Prof. Noh left out the first sentence referring to fighting: Kutiba 'alaykum alqitā lu wa huwa kurhun lakum. However, our Sufi works of tafsìrtreat the complete verse as a unit, not leaving out the first phrase.

Abd al-Karīm ibn Hawāzin al-Qushayrī (986-1074) was a prominent Arab Sufi scholar who grew up in Persia. His commentary on the whole Qur' an, Lațā 'if al-Ishārāt bi-Tafsìr al-Qur'ān, is famous for its portrayal of four layers of meaning in the Qur'an, designed variously for the common believers, the Sufi specialists, the saints, and the prophets. In his approach to QS. 2:216, he also distinguishes levels within the individual believer, which translate to different understandings of fighting, to reflect the widely discussed distinction between lesser and greater jihad:

"The engagement with fighting is difficult for the lower selves. [God] explained that the comforts of the lower selves are deferred (mu'ajjala) because they follow the ordinance of discipline ( $\left.t a^{\prime} d i b\right)$. It is the opposite of the comforts of the hearts, which are immediate (mu'ajjala) since they follow the property of drawing near (taquīb). Happiness lies in opposing (mukhā lafa) the lower selves, for anyone who conforms (wäfaqa) to them has abandoned the exemplary path (al-mahajjat almuthlā). Likewise, happiness lies in conforming (muwā faqa) to the hearts, for

atas lantai papan. Hanya arsh atas langit yang ketujuh, air bawah bumi yang ketujuh (supaya coba akan kamu siapa-siapa kamu yang terlebih a.b.a.w.q. ta'at) bagi Allah. (Dan jika engkau kata "Bahwa sanya kamu itu lagi dibangkit sekalian daripada kubur kemudian daripada mati kamu" niscaya berkata oleh segala orang-orang kafir “Tiada ini Qur' an melainkan sihir) yang bat[il] kerana tiada beriman mereka itu dengan Qur' an dan bangkit kubur." Muhammad Said bin Umar, Tafs̄ir Nūr Al-lḥ sān, vol. 2 (Patani: Maktabah wa Matbuah al-Hadi wa Auladuhu, 1971), 206-7. 
anyone who opposes (khālafa) them deviates from the highest way (al-sunnat al'ulā)." 31

A further helpful lesson can be taken from this thoughtful reflection by alQushayrī. Even though most people cannot aspire to be Sufi specialists, saints, or prophets, nevertheless most would have an instinctive sense of one's "lower self" as referred to by al-Qushayrī, namely an awareness of baser instincts that should be avoided. Such avoidance is just what al-Qushayrī advocates: happiness lies in opposing the lower selves and aspiring to a higher plane of the heart.

The Medinan verses 2:155-157 received several mentions in the literature considered earlier in this paper and, indeed, these verses often appear in discourse by Muslims about human suffering and theodicy. Those verses are:

2:155 We shall certainly test you [nabluwanna-kum] with fear and hunger, and loss of property, lives, and crops. But [Prophet], give good news to those who are steadfast,

156 those who say, when afflicted with a calamity, 'We belong to God and to Him, we shall return.'

157 These will be given blessings and mercy from their Lord, and it is they who are rightly guided.

We will turn again to the exegesis of the famous $20^{\text {th }}$-century Indonesian scholar Hamka. In commenting on verse 155, he provides a context for all of the deprivations mentioned: fear and hunger, loss of property, lives, and crops, explaining them in connection with the new community of believers in Medina:

“... from fear i.e. threats from the enemy or danger of disease and so on ...; and hunger including poverty resulting in reduced food supplies; and the lack of property, because generally the companions of the Prophet who migrated from Mecca to Medina came with their physical beings only; property could not be carried; and souls, there were deaths in the families, of children, wives and fathers; and fruit, because they no longer had extensive gardens, especially the date palms, which was the staple food of that period." ${ }^{2}$

However, the hardship described in the first part of the verse is made bearable by the promise of better times which finishes the verse on an optimistic note: "But give good news to those who are steadfast." This is explained in verses 156 and 157, where prayer, patience, and fidelity to Allah turns the bad news into the good:

31 'Abd al-Karīm ibn Hawāzin Qushayrī and Kristin Zahra Sands, Lațā'if Al-Ishārāt: Subtle Allusions. Sūras 1-4 (Louisville, KY \& Amman, Jordan: Fons Vitae \& Royal Aal al-Bayt Institute for Islamic Thought, 2017), 188-89.

32 “... dari ketakutan yaitu ancaman-ancaman musuh atau bahaya penyakit dan sebagainya ... dan kelaparan termasuk kemiskinan sehingga persediaan makanan sangat berkurang. Dan kekurangan dari hartabenda. Sebab umumnya sahabat-sahabat Rasulullah yang pindah dari Makkah ke Madinah itu hanya batang tubuhnya saja yang keluar dari sana; hartabenda tidak bisa dibawa; dan jiwa-jiwa, ada yang kematian keluarga, anak dan isteri dan bapak; dan buah-buahan, karena tidak lagi mempunyai kebun-kebun yang luas, terutama pohon kurma, yang menjadi makanan pokok pada masa itu." 
"If we creatures perform șalāt to Allah, it means that we have prayed. If we perform the șalawāt to the Messenger, it is requesting Allah that our Prophet Muhammad PBUH be given blessing and honour. But if it is Allah who gives His șalawāt to us, it means that it is the gift of His protection. Then follows Grace, which is love. And they are the ones who will be guided." 33

The Malay scholar Muhammad Said opens the door to the extensive Prophetic traditions ${ }^{34}$ in commenting on verse 156 as follows:

"156. (That is, all those who, when they are afflicted by calamity) disease or death (say: "Truly we belong to Allah) as servants, may He do with us what He wills (and that truly we will return to Him) in the Hereafter and He will repay us. According to the Hadith, whoever recites innā li'llahi wa innā ilayhi rāji ‘ $\bar{u} n$ when there is a calamity, Allah will surely reward him, replacing destruction with the best outcome." 35

The engagement with these important verses by Hamka and Muhammad Said provides us with several key insights which support the statements mentioned earlier by the Grand Imam of Jakarta's Istiqlal Mosque, Nasaruddin Umar, as well as the call by President Widodo "to work from home, learn from home, worship from home". There is an end to suffering, which is a cause for hope. In the midst of suffering, believers should be prayerful and worshipful in pursuing their normal lives. This is not a message which supports the angry rhetoric of calls such as that of the Islamic State spokesman mentioned in the introduction to this paper.

A well-known pericope occurs in Sūra Șād 38:21-25, verses from the Middle Meccan period, concerning a test to which Allah subjected prophet David. We present all six verses below so that the full context is clear:

21 Have you heard the story of the two litigants who climbed into his private quarters?

22 When they reached David, he took fright, but they said, 'Do not be afraid. We are two litigants, one of whom has wronged the other: judge between us fairly-do not be unjust-and guide us to the right path.

33 "Kalau kita makhluk ini yang mengerjakan shalat terhadap Allah, artinya telah berdoa dan shalat. Kalau kita mengucapkan shalawat kepada Rasul, ialah memohon kepada Allah agar Nabi kita Muhammad s.a.w. diberi kurnia dan kemuliaan. Tetapi kalau Tuhan Allah yang memberikan shalawatNya kepada kita, artinya ialah anugerah perlindunganNya. Kemudian itu menyusul Rahmat, yaitu kasih-sayang. Dan mereka itulah orang-orang yang akan mendapat petunjuk."Hamka, Tafsir AlAzhar, 1:351-52.

34 There are significant resources regarding appropriate responses to calamities in the Prophetic traditions but our primary focus on Sufi exegesis does not allow us to examine the Hadith literature further.

35 "Yaitu segala mereka yang apabila menganiyai akan mereka itu oleh musibah bila penyakit atau kematian kata mereka itu: "Bahwa sanya kami ini bagi Allah milik dan hamba dan kejadian memperbuat Ia pada kami akan barang yang Ia kehendaki dan bahwa sanya kami kepada-Nya kembali sekalian pada akhirat maka membalas Ia akan kami." Pada hadith barang siapa baca innā li'llahi wa innā ilayhi rāji 'ūn ketika musibah niscaya memberi pahala akan dia oleh Allah, padanya ganti ia atasnya yang terlebih baik daripada yang binasa." Umar, Tafsīr Nūr Al-ḷ̣sān, 2:47. 
23 This is my brother. He had ninety-nine ewes and I just the one, and he said, "Let me take charge of her," and overpowered me with his words.'

24 David said, 'He has done you wrong by demanding to add your ewe to his flock. Many partners treat each other unfairly. Those who sincerely believe and do good deeds do not do this, but these are very few.' [Then] David realized that We had been testing him, so he asked his Lord for forgiveness, fell down on his knees, and repented:

25 We forgave him [his misdeed]. His reward will be nearness to Us, a good place to return to.

26 'David, We have given you mastery over the land. Judge fairly between people.

Do not follow your desires, lest they divert you from God's path: those who wander from His path will have a painful torment because they ignore the Day of Reckoning.'

The Qur'anic text is clear in indicating that David was subjected to a test. The vast body of tafsir literature indicates that it related to inappropriate feelings he had towards a woman. We will turn again to the commentary by Ibn 'Arabī, via his disciple al-Kāshānī, which provides more details on David's situation:

"And did the news of the adversaries reach you when they scaled the sanctuary? And [David] thought, that is he was convinced, that We had tested him [ibtalaynāhu] with the wife of Uriah. He then sought forgiveness from his Lord, by abstaining from his sin of need [dhanbihi bi'l-iftiqār] ... And he turned to God in the annihilation of himself [bi'l-fanā' fi dhätihi], so We forgave him for that (concealing His attributes with the light of Our attributes)..." 36

Al-Kāshānī’s commentary does not provide the full detail of the interaction with the two adversaries that is available in the Qur'anic verses. It includes classical Sufi concepts which are helpful for our purposes. For example, the above text introduces the concept of fanā', annihilation, meaning suppressing the desires of the lower selves, the baser instincts, referred to in the earlier comment by al-Qushayrī on QS. 2:216 in favour of the priorities of the heart. Moreover, Verse 24 indicates that when speaking with the adversaries David realized that he was being subjected to a divine test. A question relates to the exact nature of the divine test. Did Allah send Uriah's wife to tempt David or was David's lust the result of his own bad choice and the divine test took the form of Allah sending the two disputants before him? A surface reading of the Qur' an seems to suggest that the test was in fact the disputants being sent before David, whereas Ibn 'Arabì states that Allah "had tested him (ibtalaynāhu) with the wife of Uriah."

The lesson to be taken from the test referred to in this set of verses is ambiguity surrounding the nature of divine tests. Does Allah test the faithful by deliberately placing temptation in their way or are such temptations the result of free choice by the faithful, with the test being how the faithful will deal with their own bad choices?

Our final example of divine testing is taken from a Medinan Sūra, 'Alī-'Imrān [3]: 29. Abdel Haleem's translation reads as follows:

36 Al-'Arabī, Tafsìr Al-Shaykh Al-Akbar Al- 'àrif Bi-Allāh Ta'ālā Al-'allāmah Muhyī Al-Dīn Ibn 'Arabī, $1: 168-69$

Teosofia: Indonesian Journal of Islamic Mysticism, Vol. 10, No. 2, 2021 
Say [Prophet], 'God knows everything that is in your hearts, whether you conceal or reveal it; He knows everything in the heavens and earth; God has power over all things.'

Read literally, this strong statement of God's sovereignty might cause trepidation in some readers. However, Abū'l-Qāsim al-Qushayrī steps in with a strong word of assurance: "There is nothing that escapes His knowledge, so do not be grieved by any calamity that afflicts you. Soon He will bring you succor and response, and soon the affliction and trial will disappear. He will hasten [His] assistance and protection." 37

The lesson to be taken from this exegetical comment is a message of hope, that in enduring trials and tribulations, it is important to remember that God is in charge and will lead us out of the calamities that are part of life.

\section{E. Conclusion}

Our journey through a set of Qur'anic verses that refer to divine testing has involved an encounter with six Sufi exegetes from different periods and various parts of the Muslim world: the Arab 'Abd al-Karīm ibn Hawāzin al-Qushayrī; the Persians Sahl al-Tustarī and 'Abd al-Razzāq Kamāl al-Dīn al-Kāshānī; the Ottoman Kurd Bediüzzaman Said Nursi; and the Southeast Asians Haji Muhammad Said bin Umar and Hamka. The excerpts we have considered from their writings together offer a set of lessons that are worth considering in relation to the COVID-19 pandemic. Those lessons are as follows:

1. It is important to consider both surface and underlying meanings in the Qur' anic message, not just literal readings of the verses;

2. Outward actions need to be accompanied by inward commitment in faith;

3. Behind the ritualistic duties such as the pillars are allegorical meanings which believers should seek to understand;

4. It is important to bring the faithful on the journey with the exegete, opening their eyes to realities that might not occur to them, through allegory;

5. Happiness lies in opposing the lower selves and aspiring to a higher plane of the heart;

6. There is an end to suffering, which is a cause for hope. In the midst of suffering believers should be prayerful ${ }^{38}$ and worshipful in pursuing their normal lives;

7. Ambiguity surrounds the nature of divine tests: Does Allah test the faithful by deliberately placing temptation in their way or are such temptations the result of

37 Qushayrī and Sands, Lațā'if Al-Ishārāt: Subtle Allusions. Sūras 1-4, 271.

38 Ismail Albayrak (personal communication 3 October 2021) observes: "Spiritually speaking, the power of prayer during hectic times has been multiplied from two perspectives. 1. People, who are suffering from calamities, become very sincere in their prayer. They really pray from their heart ... from sufferer's perspective. 2. Their sincerity is transferred into praise and thanks to God. Thus, God considers their prayer under the hard conditions as an extra petition for acceptance." 
free choice by the faithful, with the test rather being how the faithful will deal with their own bad choices?

8. Death should be associated with hope and optimism, not fear and pessimism;

9. In enduring trials and tribulations, it is important to remember that God is in charge and will lead us out of the calamities that are part of life.

With regard to the two key matters of debate emerging from the consideration of comments on the COVID pandemic at the outset of this paper -- whether COVID represented a divine test and whether such a test was a cause for fear or hope - the above lessons offer some helpful guidance.

First, the debate which concerns whether COVID is a divine test or a man-made problem resonates with the exegesis of QS. 38:21-26 by Ibn 'Arabī. Literalists such as the Islamic State spokesman encountered in the Introduction of this paper offer shallow, simple answers. Faithful believers are encouraged to remember the importance of allegory in interpreting the Qur'an and to shun simple literalism. In this context, they should also consider whether divine testing relates to how the faithful respond to crises rather than simply being the causative factor lying behind crises.

Second, the lessons from our various exegetes lean towards the importance of maintaining a sense of hope and optimism in the midst of calamities. Instinctive negative and hostile responses may be seen as part of our "lower selves". Believers should address both their inner and outer beings to ensure that the words of the mouth are consistent with the state of the heart. With such consistency, and with the reassurance of divine intervention and favour as seen in Hamka's commentary on QS. 2:155-157 and al-Qushayrī's commentary on QS. 3:29, believers can rest comfortably in the knowledge that present crises come with divine presence and protection. ${ }^{39}$

39 This paper has not addressed interfaith perspectives. As noted at the outset of the paper, the COVID19 pandemic is not selective in targeting faith communities. Muslims, Christians, Buddhists, Hindus and others all share a common challenge and there is much room for cooperation and partnership in facing up to one of the greatest health challenges of the $21^{\text {st }}$ century. 


\section{Bibliography}

Abdul Mu'ti. "Religious Communities Join Fight against COVID-19." The Jakarta Post. June 12, 2020. https://www.thejakartapost.com/academia/2020/06/12/religiouscommunities-join-fight-against-covid-19.html.

Al-'Arabī, Ibn. Tafsīr Al-Shaykh Al-Akbar Al-'ārif Bi-Allāh Ta'ālā Al-'allāmah Muhȳ̄ Al-Dīn Ibn 'Arabī. Vol. 1. Beirut: Dār al-Ṣadir, n.d.

Al-Kāshānī, 'Abd al-Razzāq. Great Commentaries on the Holy Qur'ān, Tafs̄ìr AlKāshānī, Part I Surahs 1-18. Amman: Royal Aal al-Bayt Institute for Islamic Thought, n.d.

Al-Tustarī, Sahl b. 'Abd Allāh. Tafsīr Al-Tustañ: Great Commentaries on the Holy Qur'ān. Edited by Annabel Keeler and Ali Keeler. Amman: Royal Aal al-Bayt Institute for Islamic Thought, 2011.

Alif Chandra. "Religious Teacher Under Investigation by MHA, Muis for Post Saying Novel Coronavirus Was Retribution from Allah against Chinese." Https://WWw.Todayonline.Com/. February $7, \quad 2020$. https://www.todayonline.com/singapore/religious-teacher-under-investigationmha-muis-racist-post-saying-novel-coronavirus-was.

Aljunied, Syed Muhd. Khairudin. Hamka and Islam: Cosmopolitan Reform in the Malay World. Singapore: ISEAS Publishing, 2018.

FMT Reporters. "Covid Is Test from God, Only Allah Can Overcome It, Says Hadi Free Malaysia Today (FMT).” https://www.freemalaysiatoday.com/, July 5, 2021. https://www.freemalaysiatoday.com/category/nation/2021/07/05/covid-is-testfrom-god-only-an-islamic-govt-can-overcome-it-says-hadi/.

Hamka. Tafsir Al-Azhar. 4th ed. Vol. 7. Singapore: Pustaka Nasional, 2001.

Hesham Abdul Khalek, Ahmed Tolba, and Ulf Laessing. "Islamic State Calls COVID19 God's Punishment for Foes: Tape.” Reuters, May 29, 2020. https://www.reuters.com/article/us-health-coronavirus-islamicstateidUSKBN2343B9.

Jayasantika, Yadi. "Ekonomi Sulit Akibat Pandemi Covid-19, Jangan Gundah Tetap Sabar Dan Istiqomah, Ini Tanda Allah Hapuskan Dosa." https://kabarbanten.pikiran-rakyat.com/, July $12, \quad 2021$. https://kabarbanten.pikiran-rakyat.com/syiar/pr-592208358/ekonomi-sulitakibat-pandemi-covid-19-jangan-gundah-tetap-sabar-dan-istiqomah-ini-tandaallah-hapuskan-dosa.

Komisi Fatwa Majelis Ulama Indonesia. "Fatwa MUI No 02 Tahun 2021 Tentang Produk Vaksin Covid-19 Dari Sinovac Life Sciences, Co. Ltd China Dan PT 
Biofarma - Majelis Ulama Indonesia.” mui.or.id, January 20, 2021. https://mui.or.id/produk/fatwa/29485/fatwa-mui-no-02-tahun-2021-tentangproduk-vaksin-covid-19-dari-sinovac-life-sciences-co-ltd-china-dan-ptbiofarma/.

Mabruroh, and Ani Nursalikah. "Menghadapi Covid-19 Dengan Tetap Percaya Kepada Allah Republika Online." Republika.Co.Id. May 1, 2021. https://www.republika.co.id/berita/qsejj4366/menghadapi-covid19-dengan-tetappercaya-kepada-allah.

Mohd Aderi Che Noh. "Ujian COVID-19 Jadikan Manusia Dekat Dengan Tuhan." Berita Harian, February 2021. https://www.bharian.com.my/rencana/agama/2021/02/783387/ujian-covid-19jadikan-manusia-dekat-dengan-tuhan.

Morales, Yusuf Roque, and Sheryl Renomeron Morales. "Responses to Fatwas of Islamic Religious Leaders and Institutions during the Coronavirus Disease (COVID-19) in the Philippines: Looking at How Guidance Was Provided to Muslim Communities in the Philippines." Turkish Journal of Computer and Mathematics Education 12, no. 10 (2020): 6160-65. https://doi.org/10.2139/ssrn.3678425.

Muhyiddin Yassin. "Speech By YAB Tan Sri Muhyiddin Bin Haji Mohd Yassin Prime Minister of Malaysia." Malaysia, April 1, 2020. https://www.pmo.gov.my/wpcontent/uploads/2020/04/English-PM-Speech-PRIHATIN-Plus-6-4-2020905pm.pdf.

Nursi, Bediüzzaman Said. Signs of Miraculousness: The Inimitability of The Qur'an's Conciseness. Edited by Şükran Vahide. Istanbul: Şözler Publications A.Ş, 2013.

Office of the Mufti. "Fatwa on Zakat Assistance for Those Affected by Covid-19." $\begin{array}{llll}\text { Singapore, } & \text { May } & 620 .\end{array}$ https://www.muis.gov.sg/officeofthemufti/Fatwa/English-Zakat-Covid.

Qushayrī, 'Abd al-Karīm ibn Hawāzin, and Kristin Zahra Sands. Lațā'if Al-Ishārāt: Subtle Allusions. Sūras 1-4. Louisville, KY \& Amman, Jordan: Fons Vitae \& Royal Aal al-Bayt Institute for Islamic Thought, 2017.

Sartika Rizki Fadilah. "Optimis PPKM Berhasil, Imam Besar Istiqlal: Kalau Kita Kompak, Covid-19 Akan Allah Angkat Dari Indonesia.” Galamedia News. July 23, 2021. https://galamedia.pikiran-rakyat.com/news/pr-352266511/optimisppkm-berhasil-imam-besar-istiqlal-kalau-kita-kompak-covid-19-akan-allahangkat-dari-indonesia?page $=2$.

Sukamto, Amos, and S. Panca Parulian. "Religious Community Responses to the Public Policy of the Indonesian Government Related to the Covid-19 Pandemic." Journal of Law, Religion and State 8, no. 2-3 (December 16, 2020): 273-83. https://doi.org/10.1163/22124810-2020006. 
Suyadi, Zalik Nuryana, and Niki Alma Febriana Fauzi. "The Fiqh of Disaster: The Mitigation of Covid-19 in the Perspective of Islamic Education-Neuroscience." International Journal of Disaster Risk Reduction 51 (December 2020): 101848. https://doi.org/10.1016/j.ijdrr.2020.101848.

Tubanur Yesilhark. "A Proper Way to Fear God and the Reality of Death." In God, Man and Mortality from the Perspective of Said Nursi. Durham: University of Durham, 2008. https://risaleinur.com/studies/137-conferences/2008/4047-a-proper-way-tofear-god-and-the-reality-of-death.html.

Umar, Muhammad Said bin. Tafs̄̄r Nūr Al-lḥsān. Vol. 2. Patani: Maktabah wa Matbuah al-Hadi wa Auladuhu, 1971. 